Al-Azhar Bull. Sci. Vol. 19, No. 2 (Dec.): pp. 13-27, 2008.

\title{
BIODEGRADATION OF SOME HYDROCARBONS IN SUEZ GULF PETROLEUM CRUDE OIL BY FUSARIUM OXYSPORUM
}

\author{
AFIFI, M. $\mathrm{M}^{\mathrm{a}}$ and BAYOUMI, R. A ${ }^{\mathrm{b}}$ \\ ${ }^{a}$ Botany and Microbiology Dept., Faculty of Science, Al-Azhar University, Assiut \\ 71524, Egypt. \\ ${ }^{b}$ Botany and Microbiology Dept., Faculty of Science (Boys), Al-Azhar University, \\ Cairo, Egypt.
}

\begin{abstract}
Among fifty fungal isolates were isolated from crude oil polluted soil samples collected from different localities in Upper Egypt (Assuit), Fusarium oxysporum C61 was selected for crude oil biodegradation due to of its high metabolic activity. The identification process of fungal genera and species resulted in fifty fungal isolates belonging to twenty six genera presented as follows: ten strains of Aspergillus, nine strains of Penicillium and one strain of Absidia, Cunninghamella, Eupenicillium, Fusarium, Nectria, Phoma and Syncephallastrum. The influence of various, $\mathrm{pH}$ values, nitrogen sources, phosphrous sources, amino acids and vitamins were investigated to obtain optimal crude oil biodegradation. The results were found to be, $\mathrm{pH} 8$, sodium nitrate, ammonium phosphate, phenylalanine, and vitamin B1, respectively. The chemical compositions of the residual crude oil were analyzed by gas chromatography mass spectrometer (GC-MS). The ability of fungal isolates to degrade crude oil as sole carbon and energy source under all optimal conditions reveled changes in some components of crude oil (not shown). Analysis of hydrocarbon components of the crude oil substrate left after the growth of $F$. oxysporium (referred to as residual crude oil) resulted in the presence of tridecanes, pentadecanes, hexadecanes, and dodecanese in reaction products, which brought about greater reduction in peak of crude oil components, relative to those of the control (undegraded).
\end{abstract}

Keywords: Petroleum crude oil; Biodegradation; Hydrocarbons; Fusarium oxysporium.

\section{Introduction}

The study of hydrocarbon degradation by microorganisms has received emphasis because of the increased incidence of petroleum based- pollution (Atlas, 1991; Bartha, 1986; Margesin and Schinner, 1997). Information by hydrocarbon degradation is needed to determine how microorganisms might be feasibly utilized in the removal of these pollutants from the environments. The microbiological decontamination of the oil- polluted soil is claimed to be an efficient economic and versatile alternative to physicochemical treatment (Bartha, 1986; Atlas, 1991). Also, Polychlorinated dibenzo-p-dioxins and dibenzofurans (PCDDs/DFs), including 2,3,7,8-substituted isomers were present in samples of shellfish and fish, and ambient air collected from Masan Bay, and Masan City, South Korea (Im et al., 
2004). A petroleum hydrocarbon (PHCs) continues to be used as the principle source of energy and hence they are stilling global environmental pollutants of interest. The world crude oil production is approximately 3 billion tons/year, with roughly $70 \%$ of this production transported by sea. A part from accidental contamination of ecosystem, the vast a mounts of oil sludge generated in refineries from water oil separation systems and accumulation of waste oily materials in crude oil storage tank bottoms pose great problems because of the extensive disposal methods (Ferrari et al., 1996; Vasudevan and Rajaram, 2001).Despite decades of research, successful bioremediation of petroleum hydrocarbon contaminated soil remains a challenge. Petroleum hydrocarbons enter surface and subsurface soils from accidental spills of crude oil and fuels from the large pipeline networks buried below the surface. These subsoil conduits carry large volumes of crude petroleum offshore and on-shore, from oil exploration and production field operations to refineries to bulk storage terminals. The amount of crude oil spilled on land due to pipeline failures is estimated to be 40.000 barrels per year (1.680.000 gallons) or $70 \%$ of all oil discharged to soil and water bodies (Salanitro, 2000). The technology has been usefully employed in the removal of a class of organic pollutants known as hydrocarbons; primarily being used to promote the removal of these compounds from soil, industrial wastewater, surface water reservoirs, and ground water aquifers (Lehmann, 1998). As it is well known, the Red Sea suffers from oil pollution especially around the oil fields in the Suez Gulf. The exposure of water in this area to many types of petroleum crude oil contaminations has drawn our thinking to study the possibility of the crude oil biodegradation by fungal strains isolated from pollutant source.

The purposes of this work were to (i) collect a number of aerobic culturable hydrocarbon degrading fungal isolates from different soil samples collected from upper Egypt (Assuit), (ii) identify of the hydrocarbon utilizing fungal isolates by morphological characteristics according to standard keys, (iii) investigate the biodegradation activity of the selected fungal strains by mean dry weight and selection of the most potent one and (iv) investigate some parameters controlling the growth and biodegradation of some hydrocarbons in crude oil by best one fungal isolate.

\section{Materials and methods Fungal strains:}

Different fungal colonies isolated from petroleum crude oil polluted soil samples were collected from different localities in upper Egypt (Assuit). The fungal isolates 
were identified on the basis of morphological characteristics and microscopic examination with the help of keys of (Raper and Fennell, 1965; Booth, 1971; Ellis, 1971; 1976; Pitt, 1979; Domsch et al., 1980; Moubasher, 1993; Pitt and Hocking, 1997; Barnett and Hunter, 1999). The identified fungal strains were maintained routinely in the laboratory on potato dextrose agar (PDA) slants at $4{ }^{\circ} \mathrm{C}$.

\section{Characterization of Crude oil:}

The physico-chemical properties of Suez gulf petroleum co. (GUPCo) was determined according to standard methods by Bayoumi and Abdullh, (2004). The GUPco was characterized by the flowing: Density, 0.9456; specific gravity, 0.9465, API, 18; Kinematic viscosity (cSt), 16.73; Pour point, 18 (C); sulfur content, 1.77 (wt\%); asphaltene content, 3.89 (wt\%); resin content, 18.15 (wt\%), oil content 77.95 $(\mathrm{wt} \%)$.

\section{Culture conditions:}

The various fungal strains were inoculated by 7-days old cultures on PDA. For oil degradation studies, 0.2 (v/v), crude oil was added to $100 \mathrm{ml}$ culture medium in a series of $250 \mathrm{ml}$ flasks, with the petroleum crude oil serving as supplemented carbon and energy sources. The media used were mineral salts medium (MSM), which contained (g/l): $\mathrm{KH}_{2} \mathrm{PO}_{4}, 1 ; \mathrm{MgSO}_{4} \cdot 7 \mathrm{H}_{2} \mathrm{O}, 0.5 ; \mathrm{KCl}, 0.05$. Two $\mathrm{ml}$ of crude oil sample were emulsified gently with $2 \mathrm{gm}$ of Arabic gum in a clean porcelain mortar. The previously heated media was added gently until a homogenous suspension was obtained then inoculated and incubated at $28^{\circ} \mathrm{C}$ for 5 days. Control was flasks containing uninoculated medium. The biomass produced was recovered by filtration through pre-extracted, dried, and weighed by Whitman filter paper (No.113). The mycelium residues were washed with $50 \mathrm{ml}$ diethyl ether to remove oil residues. The mycelium was dried at $60^{\circ} \mathrm{C}$ to a constant weight, being cooled in desiccators before dry weight determination. Mean \pm SD of dry weight has been carried out for three replicates.

To optimize crude oil biodegradation mainly, various; $\mathrm{pH}$ values $(2,4,6,8$, and 10); nitrogen sources (calcium nitrate, ammonium chloride, ammonium. nitrate, potassium nitrate, and silver nitrate); phosphorous sources (sodium monohydrogen phosphate, sodium dihydrogen phosphate, potassium monohydrogen phosphate, ammonium. phosphate and potassium dihydrogen phosphate); amino acids (phenylalanine, asparagine, methionine, aspartic acid, lysine and isoleucine); and vitamins (vitamin B6, Vitamin B1, folic acid, and riboflavin), were investigated. 
Crude oil basal salts broth (COBSB) medium was adjusted at various $\mathrm{pH}$ values in the flasks $(250 \mathrm{ml})$ only $100 \mathrm{ml}$ for each one by using $\mathrm{HCl}-\mathrm{NaOH}$ buffer. Each treatment of sodium, phosphorous, amino acid, and vitamin was added to COBSB medium in concentration $0.1 \%(\mathrm{w} / \mathrm{v})$ in triplicate flasks.

\section{Hydrocarbon recovery and analysis:}

Residual crude oil in each flask were extracted with chloroform $(33 \mathrm{ml})$, and concentrated by evaporation under a nitrogen flow (Bayoumi and Abdallah, 2004). After solvent evaporation, the dried extract was re-dissolved in $0.5 \mathrm{ml}$ chloroform, 0.1 aliquots was analyzed by SHIMADZU-QP 5050A GC-MS.

The injection temperature was $300^{\circ} \mathrm{C}$ and the hydrocarbon fractions were fractionated on a Perkin Elmer Sigma capillary column $(50 \mathrm{~cm}$ x $0.5 \mathrm{~mm})$. The oven temperature was programmed from 75 to $300^{\circ} \mathrm{C}$, increasing of $5^{\circ} \mathrm{C} \mathrm{min}^{-1}$. The carrier

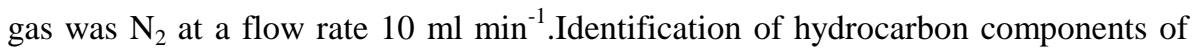
the crude oil was by comparison with retention times of hydrocarbon standards, while the extent of degradation (\%) was calculated by comparing the decrease in the peak areas relative to those of the control (undegraded).

\section{Data analysis:}

The data obtained for each parameter were evaluated and submitted for analysis of variance by $\mathrm{F}$. test. The mean value was compared at 5\% level of significance using the last significance differences (LSD) test (Gomez and Gomez, 1984).

\section{Results and discussion}

Preliminary experiments showed that the fungus Fusarium oxysporum C61 could metabolize crude oil among fifty tested fungal strains.

Table (1) depicts a summary of identification, and screening processes of fungal strains relative to their biodegrading abilities. The analysis of variance ( $\mathrm{F}$. test), showed a high significance in Fusarium oxysporum C61 between the tested fungi, and resulted in $1.68 \pm 0.04 \mathrm{~g} / 100$ dry biomass over that resulted in the other genera. 
Table (1): Biodegrading abilities of the twenty-six identified fungal strains.

\begin{tabular}{|llcc|}
\hline No. & Fungal isolates & No. of strains & $\begin{array}{c}\text { Mean dry weight } \\
(\mathrm{g} / 100 \mathrm{ml}) \pm \mathrm{SD}^{*}\end{array}$ \\
\hline 1 & Absidia corymblfra & 1 & $0.75 \pm 0.01$ \\
2 & Aspergillus candidus & 2 & $0.97 \pm 0.01$ \\
3 & Aspergillus flavus & 4 & $0.85 \pm 0.01$ \\
4 & Aspergillus flavipes & 1 & $0.92 \pm 0.02$ \\
5 & Aspergillus fumigatus & 4 & $0.91 \pm 0.01$ \\
6 & Aspergillus niger & 4 & $0.88 \pm 0.02$ \\
7 & Aspergillus ochraceus & 4 & $0.96 \pm 0.01$ \\
8 & Aspergillus oryzae & 1 & $0.94 \pm 0.01$ \\
9 & Aspergillus tamari & 2 & $1.43 \pm 0.03$ \\
10 & Aspergillus terreus & 5 & $0.91 \pm 0.01$ \\
11 & Aspergillus versicolor & 2 & $1.32 \pm 0.02$ \\
12 & Cunninghamella elegans & 1 & $0.96 \pm 0.01$ \\
13 & Eupenicillium alutaceum & 1 & $0.90 \pm 0.01$ \\
14 & Fusarium oxysporum & 1 & $1.68 \pm 0.04$ \\
15 & Nectria haematococca & 1 & $1.51 \pm 0.01$ \\
16 & Penicillium chrysogenum & 1 & $0.67 \pm 0.01$ \\
17 & Penicillium citrinum & 1 & $0.91 \pm 0.02$ \\
18 & Penicillium canescens & 2 & $0.82 \pm 0.01$ \\
19 & Penicillium duclauxii & 2 & $0.91 \pm 0.01$ \\
20 & Penicillium funiculosum & 2 & $0.92 \pm 0.02$ \\
21 & Penicillium glabrum & 1 & $0.90 \pm 0.01$ \\
22 & Penicillium islandicum & 1 & $0.82 \pm 0.02$ \\
23 & Penicillium janczewskii & 2 & $0.95 \pm 0.01$ \\
24 & Penicillium variabile & 2 & $1.01 \pm 0.04$ \\
25 & Phoma glomerata & 1 & $0.88 \pm 0.01$ \\
26 & Syncephalastrum racemosum & $0.76 \pm 0.01$ \\
\hline & & 1 & \\
\hline
\end{tabular}

$* \mathrm{P}>0.0000 ; \mathrm{F}$. value, 2553.28; $\mathrm{LSD}_{0.03}=0.016$.

After an extensive identification of fungal genera and species isolated from polluted soil in Upper Egypt (Assuit), fifty fungal isolates were observed, belonged to twenty-six fungal genera, which identified and /or characterized as follows: ten species of Aspergillus, nine species of Penicillium and one species of Absidia, Cunninghamella, Eupenicillium, Fusarium, Nectria, Phoma and Syncephallastrum. The genera Aspergillus and Penicillium were the most dominant. Our results agree with (Nyns et al., 1968; Al-Gounaim and Diab, 1998; April et al., 2000; Diab, 2000; Bayoumi and Abdallh, 2004; Chaillan et al., 2004; Eshafie et al., 2007). 
Snellman et al., (1988) isolated a number of fungi from tar balls including Aspergillus and Penicillium species, which were also isolated from petroleumcontaminated soil in Saudi Arabia (Bokhary and Parvez,1993; Hesham, 1995). The presence of oil degrading microorganisms such as bacteria and fungi is not restricted to a particular ecosystem and has been found in the Arctic, Antarctic and temperature regions but little work has been reported in high temperature ecosystems (Prince, 1993). Several fungi were found to exhibit greater hydrocarbon biodegradation than bacteria (Cerninglia and Perry,1973) and thus differ in their abilities to utilize n-alkane and crude oil (Snellman et al., 1988; Bakhary and Parvez, 1993). Nevertheless, very few studies have been conducted on the ability of filamentous fungi to utilize pure aliphatic hydrocarbons.

Davis and Westlake (1979) reported that 28 out of 34 fungi they studied were capable of growing on a variety of crude oil. Compared with isolates of other fungi, Aspergillus and Penicillium isolates were reported to be rich in hydrocarbon assimilatory strains were capable of crude oil degradation (Fedorack et al., 1984;Hashim,1995). In this study Aspergillus tamari, Aspergillus versicolor, Fusarium oxysporum and Nectria haemotococca (Table 1) and Fusarium oxysporum was selected as best one for more detailed studies. Fungi show tremendous diversity and adaptability in utilization of different organic molecules as a carbon source however, their abilities to degrade a specific hydrocarbon as a source of energy and / or biomass may differ. The chemical composition of a crude oil may also be a factor in determining the type of fungi, which may grow on it (Davies and Westlake,1979). Chaillan et al., (2004) isolated of different fungal genera from petroleum-polluted soils belonging to Aspergillus, Penicillium, Fusarium, Amorphoteca, Neosartorya, Pacilomyces, Talaromyces and Graphium in synthetic liquid media with crude oil as sole carbon and energy source.

All the biodegradation parameters in the present study were carried out at $30^{\circ} \mathrm{C}$. Temperature plays very important roles in biodegradation of petroleum hydrocarbons, firstly by its direct effect on the chemistry of the pollutants and secondly on its effect on the physiology and diversity of the microbial milieu. Ambient temperature of an environment affects both the properties of spilled oil and the activity or population of microorganisms (Venosa and Zhu,2003). At low temperature, the viscosity of the oil increases, while the volatility of toxic low molecular weight hydrocarbons is reduced delaying the onset of biodegradation. Temperature also variously affects the solubility of hydrocarbons. Although hydrocarbon biodegradation can occur over a wide range of temperature, the rate of 
biodegradation generally decreases with decreasing temperature. Highest degradation rates generally occur in the range of $30-40^{\circ} \mathrm{C}$ in soil environments, 20 $30^{\circ} \mathrm{C}$ in some fresh water environments (Cooney,1984). Temperature plays a significant role in controlling the nature and extent of microbial hydrocarbon metabolism (Nedwell,1999).Temperature affects the rate of biodegradation, as well as the physical nature and chemical composition of hydrocarbons (Rowland et al., 2000). A temperature increase leads to a diffusion rate of organic compounds notably a decrease of their viscosity.

Successful application of bioremediation technology to contaminated systems requires knowledge of the parameters that affect the microbial biodegradation of pollutants (Sabate et al., 2004). In figure(1), the effect of $\mathrm{pH}$ on crude oil biodegradation was clarified by Fusarium oxysporum C61. It was found that, $\mathrm{pH} 8$ achieved maximum biodegrading ability. Figures (2-5), exhibit the effect of different parameters on the degradation rate of crude oil. It was noted that, the addition of sodium nitrate, ammonium phosphate, phenylalanine and vitamin B1, enhanced biomass development in $F$. oxysporium C61. The highest biomasses (mean dry weight, $\mathrm{g} / 100 \mathrm{ml}$ ) were $0.91 \pm 0.01,0.93 \pm 0.02,0.98 \pm 0.01$, and $0.89 \pm 0.02$ in case of, nitrogen source, phosphorous source, amino acid, and vitamin, respectively. Significant differences were observed in crude oil degradation among all treatments. The most important factor affecting biodegradation of petroleum hydrocarbons include $\mathrm{pH}$. The $\mathrm{pH}$ of seawater is generally stable and slightly alkaline (Bossert and Bartha,1984). In contrast, the $\mathrm{pH}$ of freshwater and soil environments can vary widely. Organic soils in wetlands are often acidic, while mineral soils have more neutral and alkaline conditions. Most heterotrophic bacteria and fungi favor a neutral $\mathrm{pH}$, with fungi being more tolerant of acidic conditions. Studies have shown that degradation of oil increases with increasing $\mathrm{pH}$ and that optimum degradation occur under slightly alkaline conditions.

Nutrients are very important ingredients for successful biodegradation of hydrocarbon pollutants, especially nitrogen, phosphorous and in some cases iron (Cooney,1984). Depending on the nature of the impacted environment, some of these nutrients could become limiting thus affecting the biodegradation processes. When a major oil spill occurs in marine and freshwater environments, the supply of carbon in dramatically increased and the availability of nitrogen and phosphorus generally becomes the limiting factor for oil degradation. The effect of nutrients amendment was much more pronounced on the assimilation of linear and branched alkanes than on cyclic alkanes indicating that nutrient amendment stimulates preferentially the microorganisms that assimilate paraffin hydrocarbons. 


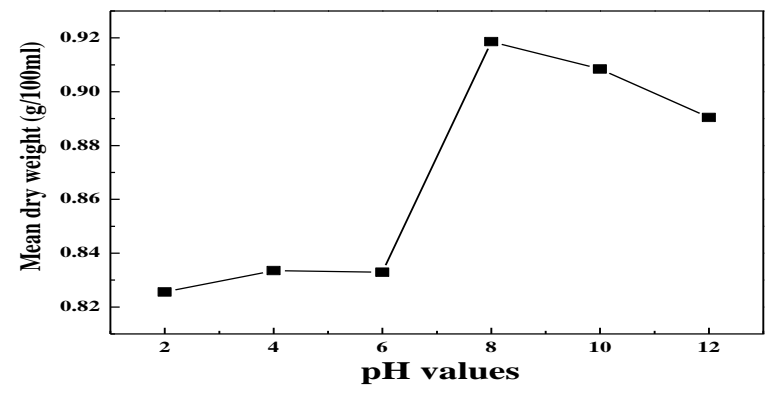

Fig.(1): Effect of different $\mathrm{pH}$ values to the biodegradation power of crude oil by Fusarium oxysporum C61. P> 0.0000; F. value, 148.36; $\mathrm{LSD}_{0.05}=0.02$.

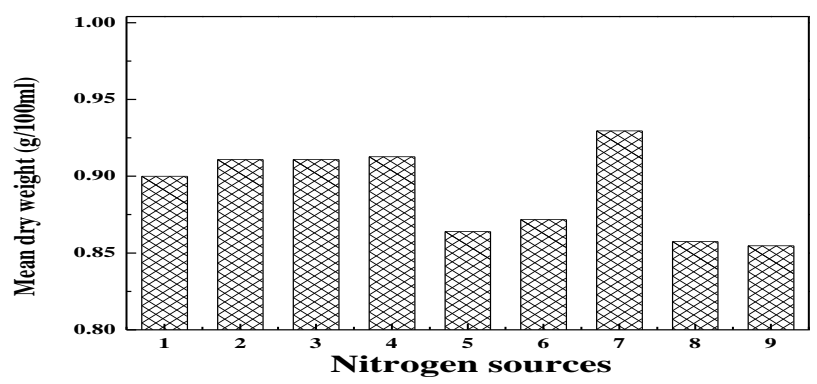

Fig.(2): Effect of different of nitrogen sources to the biodegradation of crude oil by $F$. oxysporum C61. 1, calcium nitrate; 2, ammonium chloride; 3, ammonium nitrate; 4, potassium nitrate; 5 , silver nitrate; 6 , ammonium sulphate; 7 , sodium nitrate; 8, ammonium persulphate and 9, ammonium peroxide sulphate. $\mathrm{P}>0.0000 ; \mathrm{F}$. value, $81.73 ; \mathrm{LSD}_{0.05}=0.017$.

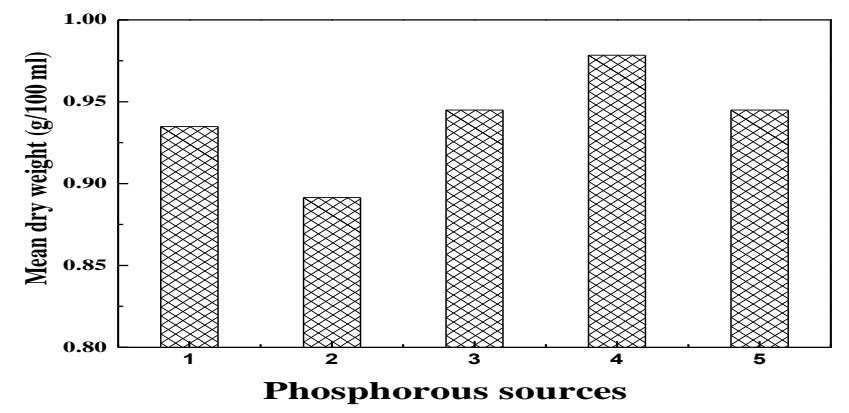

Fig.(3): Effect of different phosphorous sources to biodegradation of crude oil by $F$. oxysporum C61. 1, sodium monohydrogen phosphate; 2, sodium dihydrogen phosphate; 3 , potassium monohydrogen phosphate; 4 , ammonium phosphate and 5, potassium dihydrogen phosphate. $\mathrm{P}>0.0001$; $\mathrm{F}$. value, $43.89 ; \mathrm{LSD}_{0.03}=$ 0.02 . 


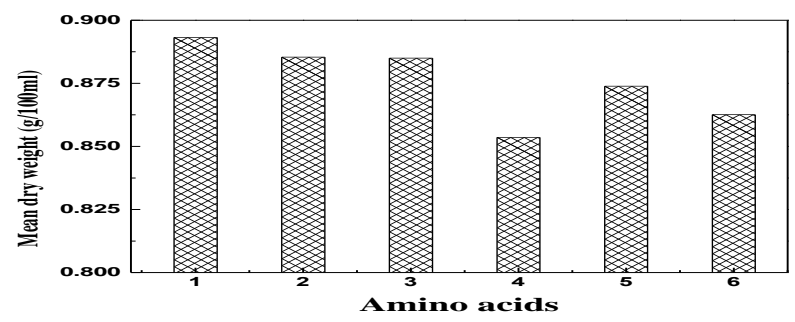

Fig.(4): Effect of different amino acids to the biodegradation of crude oil by $F$. oxysporum C61. 1, phenylalanine; 2, asparagine; 3, methionine; 4, aspartic acid; 5, lysine and 6, isoleucine. $\mathrm{P}>0.0000 ; \mathrm{F}$. value, 13.07; $\mathrm{LSD}_{0.05}=0.02$.

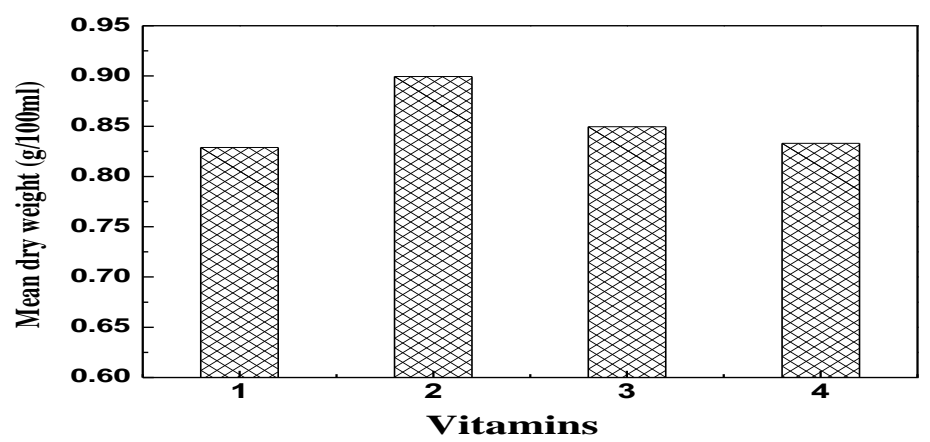

Fig.(5): Effect of different vitamins to the biodegradation of crude oil by $F$. oxysporum C61.1, vitamin B6; 2, vitamin B1; 3, folic acid; and 4, riboflavin. P>0.0001; F. value, $67.27 \mathrm{LSD}_{0.05}=0.02$.

\section{Hydrocarbon Analysis:}

Results recorded in tables (2\&3) and represented graphically in figures (6\&7), shows a typical GC-MS profile of crude oil components, with the following retention time ( $\mathrm{min}$ ): decane, 27.7; dodecane, 30.6; tridecane, 33.3; pentadecane, 35.9; hexadecane, 38.5; heptadecane, 40.9; octadecane, 43.2; eicosane, 45.4; and docosane, 47.7 .

The use of GC-MS showed the presence of fungal reaction products, with the following retention time ( $\mathrm{min})$ : tridecane, 33.2; pentadecane, 35.9; hexadecane, 38.4; and docosane, 47.6, which brought about greater reduction in peak of crude oil components (Fig.7). This agree with Bartha,(1986); Jakson and Pardue,(1999); Chang and Weaver,(1997); Bayoumi and Abdallh, (2004). 
Most fungi utilize crude oil as a source of carbon and energy and the hydrocarbons molecules are metabolized to $\mathrm{CO}_{2}$ and biomass. The highest biomass was obtained by Aspergillus tamari, Aspergillus versicolor, Fusarium oxysporum and Nectria haematococca (Table1), which is highly correlated with highest oil utilization. In this study, Fusarium oxysporum was found to utilize different some hydrocarbons (Table $2 \& 3$ ). This could be explained by the fact that the ability to utilize oil as a sole carbon source in not a stable physiological characteristic present in all members of the same genus or isolated fungal genera. The chemical composition of a crude oil determines the type of fungi, which grow on it and some fungi may grow on some crude oil and not others. These result agreement with Lowery et al., (1968) who noted great diversity in the abilities of fungi were noted on hydrocarbons. Varying responses of fungi were noted on hydrocarbons. Prince (1993) reported that microorganisms show a distinct preference for some hydrocarbons over others. Some hydrocarbons were reported to be lethal to some fungi and others were not as toxic (Nynes et al., 1968).

Table 2. GC-MS chromatogram of hydrocarbons components of crude oil before fungal treatment.

\begin{tabular}{|c|c|c|c|}
\hline Serial no. & $\begin{array}{c}\text { Hydrocarbon } \\
\text { compound }\end{array}$ & $\begin{array}{c}\text { Height A/H(sec) } \\
(\text { Area \%) }\end{array}$ & $\begin{array}{c}\text { Retention } \\
\text { Time(minutes) }\end{array}$ \\
\hline 1 & Decane & 11.347 & 27.775 \\
\hline 2 & Ddodecane & 12.173 & 30.641 \\
\hline 3 & Tridecane & 12.724 & 33.375 \\
\hline 4 & Pentadecane & 13.391 & 35.992 \\
\hline 5 & Hexadecane & 13.017 & 38.500 \\
\hline 6 & Heptadecane & 13.039 & 40.905 \\
\hline 7 & Octadecane & 13.198 & 43.218 \\
\hline 8 & Eicosane & 13.099 & 45.439 \\
\hline 9 & Docosane & 12.775 & 47.785 \\
\hline
\end{tabular}

Table 3. GC-MS chromatogram showing the presence of hydrocarbons compounds after fungal biodegradation.

\begin{tabular}{|c|c|c|c|}
\hline Serial no. & $\begin{array}{c}\text { Hydrocarbon } \\
\text { compound }\end{array}$ & $\begin{array}{c}\text { Height A/H(sec) } \\
\text { (Area \%). }\end{array}$ & $\begin{array}{c}\text { Retention } \\
\text { Time(minutes) }\end{array}$ \\
\hline 1 & Tridecane & 12.70 & 33.29 \\
\hline 2 & Pentadecane & 13.33 & 35.90 \\
\hline 3 & Hexadecane & 13.17 & 38.41 \\
\hline 4 & Docosane & 12.25 & 47.67 \\
\hline
\end{tabular}




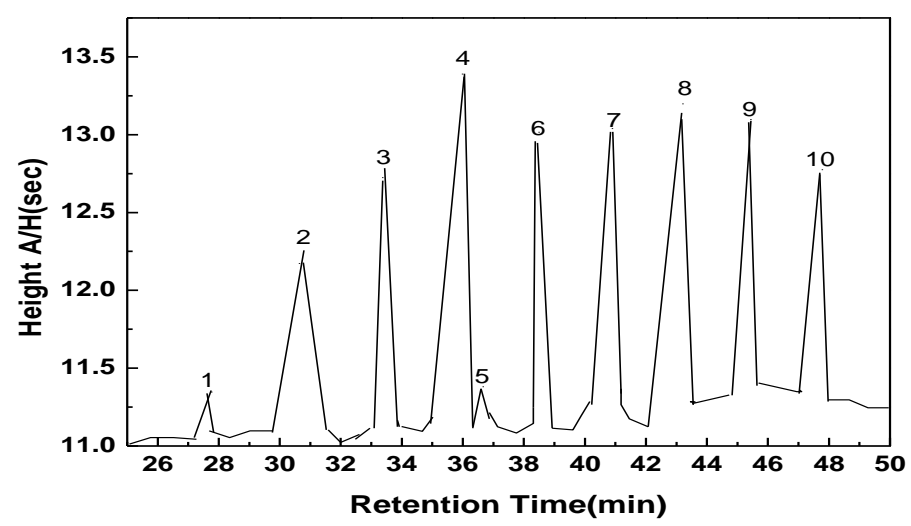

Fig. (6): GC-MS chromatogram of hydrocarbons components of crude oil before fungal treatment. 1. decane, 2 . dodecane, 3. tridecane , 4. pentadecane, , 6. hexadecane, 7. heptadecane, 8. octadecane, 9. eicosane, 10. docosane.

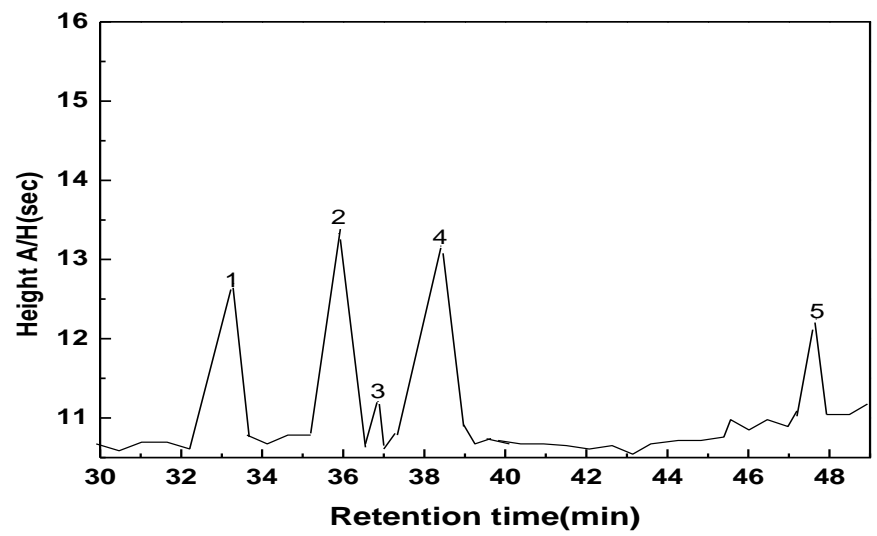

Fig. (7): GC-MS chromatogram showing the presence of hydrocarbons components of fungal reaction products. 1. tridecane, 2. pentadecane, 4 . hexadecane and 5. docosane.

Recently, attention has been given to the use of microbial consortia of PAHs degraders consisting of bacteria and fungi. Compared to pure cultures, these consortia have been more effective in the degradation of these compounds, due the capacity to use a larger number of PAHs and higher degradation and mineralization rate In Vitro and in soil (Boonchan et al., 2000; Kohlmeier et al., 2005; Wick et al., 2007; Xiaojun et al., 2008). 


\section{Conclusions}

The results obtained in the present study confirmed that the inoculation of Fusarium oxysporium C61 to degrade in oil-contaminated Egyptian sues gulf could be considered as a potential method. However, more than fifty percent of hydrocarbons components were removed. Therefore, it was an acceptable method to use the present fungal strain to biodegrade crude oil from contaminated Egyptian Suez Gulf area. Finally, with the understanding of the variation of fungal hydrocarbon degradation in the laboratory experiments, it would the possible to develop strategies for using fungi for the removal of hydrocarbons from contaminated sea water before they develop into tar balls that might pollute the Red Sea and Suez Gulf beaches in Egypt.

\section{References}

1. AL-GOUNAIM, M.Y. AND DIAB, A. (1998): Ecological distribution and biodegradation activities of oil-degrading marine bacteria in the Arabian Gulf water at Kuwait. Arab. Gulf. J. Sci. Res. 16: 359-377.

2. APRIL, T. M., FOGHT, J. M. AND CURRAH, R. S. (2000): Hydrocarbon-degrading filamentous fungi isolated from flare pit soils in northern and western Canada. Can. J. Microbiol. 46: 38-49.

3. ATLAS, R. M. (1991): Microbial hydrocarbon degradation-bioremediation of oil spills. J. Chem. Technol. Biotechnol. 52:149-156.

4. BARNETT, H. L. AND HUNTER, B. B. (1999): Illustrated genera of imperfect fungi. $4^{\text {th }}$ edition. $2^{\text {nd }}$ printing, APS press. The American Phytopathological Society. StPaul, Minnesota, pp, 218.

5. BARTHA, R. (1986): Biotechnology of petroleum pollutants biodegradation. Microbial Ecology, 12: 155-172.

6. BAYOUMI, R. A. AND ABDALLH, R. I. (2004): Bioremediation of heavy and light crude oils by some fungal isolates. Egypt. J. of Biotechnol. 16: 133-149.

7. BOKHARY, H. A. AND PARVEZ, S. (1993): Fungi from petroleum contaminated Saudi Arabian soils. Arid Soil Research and Rehabilitation.7(2),191-195.

8. BOONCHAN, S., BRITZ, M. I. AND STANLEY, G. A. (2000): Degradation and mineralization of high-molecular-weight polycyclic aromatic hydrocarbons by defined fungal-bacterial cocultures, Appl. Environ. Microbiol. 66,1007-1019.

9. BOOTH, C. (1971): The genus Fusarium. Common Wealth Mycological Institute, Kew Surrey, England, pp. 273.

10. BOSSERT, I. AND BARTHA, R. (1984): The fate of petroleum in soil Ecosystems. In 
Petroleum Microbiology, RM Atlas(ed.) Macmillan, New York,pp.453-473.

11. CERNINGLIA, C. E. AND PERRY, J. J. (1973): Crude oil degradation by microorganisms isolated from the marine environment. Zaitsc. Allg. Microbiol. 13(4), 299-306.

12. CHAILlAN, F., LE-FLECHE, A., BURY, E., PHANTAVONG, Y. H., GRIMONT, P., SALIOT, A. AND OUDOT, J. (2004): Identification and biodegradation potential of tropical aerobic hydrocarbon-degrading microorganisms. Research in Microbiol.155:587595.

13. CHANG, Z. Z. AND WEAVER, R. W. (1997): Nitrification and utilization of ammonium and nitrate during oil bioremediation at different soil water potentials. Journal of Soil Contamination. 6: 2, 149-160.

14. COONEY, J. J. (1984): The fate of petroleum pollutants in freshwater ecosystems.K03099-Pollution;J 02905 water ;P 2000 Freshwater Pollut.

15. DAVIS, J. S. AND WESTLAKE, D. W. S. (1979): Crude oil utilization by fungi. Can .J. Microbiol. 25, 146-156.

16. DIAB, E. A. (2000): The role of some microorganisms in the removal of oil pollution from soil. M.Sc. Thesis. Department of Biological and National Sciences, Institute of Environmental Studies and Research, Ain Shams University, Cairo, Egypt.

17. DOMSCH, K. W.; GAMES, W. AND ANDERSON, T. (1980): Compendium of soil fungi, Academic Press, London.

18. ELLIS, M. B. (1971): Dematiaceous hyphomycotes. Common Wealth Mycological Institute, Kew, Surry, England.

19. ELLIS, M. B. (1976): More Dematiceous Hyphomycetes. Common Wealth Mycological Institute, Kew Surrey, England. pp. 507.

20. ELSHAFIE, A., ALKINDI, A. Y., AL-BUSAIDI, S., BAKHEIT, C. AND ALBAHRY, S. N. (2007): Biodegradation of crude oil and n-alkanes by fungi isolated from Oman. Marine Pollu. Bulletin.54,1692-1696.

21. FEDORACK, P. M., SEMPLE, K. M. AND WESTLAKE,D.W.S.(1984): Oil-degrading capabilities of yeasts and fungi isolated from coastal marine environments. Can.J. Microbiol. 30, 565-571.

22. FERRARI, M. D.; NEIROTTI, E.; ALBORNOZ, C.; MOSTAZO, M. R. ANDCOZZO, M. (1996): Biotretment of hydrocarbons from petroleium tank bottom sludges in soil slurries. Biotechnol. Lett. 18, 1241-1246.

23. GOMEZ, K. A. AND GOMEZ, A. A. (1984): Statistical procedures for agricultural research. Gohn Wiley \& Sons. Inc. NewYork, USA.

24. HESHAM, A. R. (1995): Soil analysis and mycoflora of the Jubail Industrial city in Saudi Arabia. J.Univ. Kuwait (Sci.)22,231-237. 
25. IM, S. H.; STRAUSE, K. D.; GIESY, J. P.; CHANG, Y. S.; MATSUDA, M.; WAKIMOTO, T.ANDCHEMOSPHERE, A., (2004): Concentrations and accumulation profiles of polychlorinated dibenzo-p-dioxins and dibenzofurans in aquatic tissues, and ambient air from South Korea. Jun; 55 (10): 1293-302.

26. JACKSON, W. A. AND PARDUE, J. H. (1999): Potential for intrinsic and enhanced crude oil biodegradation in Louisiana's freshwater marshes. Wet lands. 19: 1, 28-34.

27. KOHLMEIER, S.; SMITS, T. H.; FORD, R. M.; KEEL, C.; HARMS,H. AND WICK, L. Y. (2005): Taking the fungal highway: mobilization of pollutant-degrading bacteria by fungi, Environ. Sci. Technol. 39, 4640-4646.

28. LEHMANN, V. (1998): Bioremediation: A solution for polluted soils in the south. Biotechnology and Development Monitor No. 34, pp. 12-17.

29. LOWERY, C. E., FOSTER, J. W. AND JURTSHUK, P. (1968): The growth of various filamentous fungi and yeasts on n-alkanes and ketones. I. Studies on substrate specificity. Archiv. Microbiol.60,246-254.

30. MARGESIN, R. AND SCHINNER, F. (1997):Efficiency of indigenous and inoculated cold adapted soil microorganisms for biodegradation of diesel oil in Alpine soils. Appl. Environ. Microb. 63: 2660-2664.

31. MOUBASHER, A. H. (1993): Soil fungi of Qatar and other Arab Countries. The Scientific and Applied Research Centre, University of Qatar, Doha, Qatar. pp. 566.

32. NEDWELL, D. B. (1999): Effect of low temperature on microbial growth: Towered affinity for substrates limits growth at low temperature. FEMS Microbiol.Ecol.30,101111.

33. NYNS, E. J.; AUQUIERE, I. P. AND WIAUX, A. L. (1968): Taxonomic value of propery of fungi to assimilate hydrocarbons, Antonie Van Leeuwenhoek, J. Microbiol. Serol., 34: 441-457.

34. PITT, J. I. (1979): The Genus Penicillium and its telomorphic states Eupenicillium and Talaromyces. London, Academic press.

35. PITT, J. I. AND HOCKING, A. D. (1997): Fungi and food spoilage. $2^{\text {nd }}$ ed. Aspen Publisher, Gaithersburg, M. D.

36. PRINCE, R. C. (1993): Petroleum spill bioremediation in marine environment. Crit. Rev. Microbiol. 19(4),217-242.

37. RAPER, K. B. AND FENNELL, D. I. (1965): The genus Aspergillus. Williams and Wilkins, Baltimore, USA.

38. ROWLAND, A. P., LINDLEY, D. K., HALL, M. J., ROSSALL, M. J., WILSON, D. R., BENHAM, D. G., HARRISON, A. F., DANIELS, R. E. (2000): Effect of beach sand properties, temperature and rainfall on the degradation rates of oil in buried oil/beach sand mixtures.Environ.Pollut.109,109-118. 
39. SABATE, J. VINAS, M. AND SOLANAS, A. M. (2004): Laboratory-Scale bioremediation experiments on hydrocarbon-contaminated soils. Internl. Biodeter. Biodegrad. 54:19-25.

40. SALANITRO, J. P. (2000): Oil pollution. In "Encyclopedia of Microbiology" (J. ederberg. Ed.) . $2^{\text {nd }}$ ed., Vol. 3, pp. 449-455. Academic Press. San Diego. CA.

41. SNELLMAN, R. P., COLLINS, P. AND COOKE, J. C. (1988): Utilization of fuel oils by fungi isolated from oceanic tar balls. Lett. Appl.Microbiol.6, 105-107.

42. VASUDEVAN, N. AND RAJARAM, P. (2001): Bioremediation of oil sludge contaminated soil. Environ. Int. 26, 409-411.

43. VENOSA, A. D. AND ZHU, X. (2003): Biodegradation of crude oil contaminating Marine Shorelines and Freshwater Wetlands. Spill Sci.Tech.Bull. 8(2):163-178.

44. WICK, L. Y., EMER, R., ÜRZ, B., EICHENBACH, J., RAUN, S., CHÄFER, F. AND HARMS, H. (2007): Effect of fungal hyphae on the access of bacteria to phenanthrene in soil, Environ. Sci. Technol. 41, 500-505.

45. XIAOJUN, L I., PEIJUN, LI., XIN, L I., CHUNGUI, Z H., QI, L I. AND ZONGQIANG, GO. (2008): Biodegradation of aged polycyclic aromatic hydrocarbons (PAHs) by microbial consortia in soil and slurry phases. Journal of Hazardous Materials. 15(1): 2126. 